\title{
Auditing the AUDIT: A systematic review of cut-off scores for the Alcohol Use Disorders Identification Test (AUDIT) in low- and middle-income countries*
}

Abhijit Nadkarni ${ }^{\mathrm{a}, \mathrm{b}, \mathrm{c}, \mathrm{d} * \S}$, Alison Garber ${ }^{\mathrm{a}, \mathrm{e}}$, Sheina Costa ${ }^{\mathrm{a}}$, Sheena Wood ${ }^{\mathrm{a}, \mathrm{e}}$, Sonali Kumar ${ }^{\mathrm{a}}$,

Nathalie MacKinnon ${ }^{\mathrm{a}, \mathrm{f}}$, Mariam Ibrahim ${ }^{\mathrm{a}}$, Richard Velleman ${ }^{\mathrm{a}, \mathrm{g}}$, Urvita Bhatia ${ }^{\mathrm{a}}$, Godwin

Fernandes $^{\mathrm{a}}$, Benedict Weobong ${ }^{\mathrm{a}}$, Anil Rane ${ }^{\mathrm{h}}$

aAddictions Research Group, Sangath, H No 451 (168), Bhatkar Waddo, Socorro, Porvorim, Bardez, Goa, 403501 India

${ }^{\mathbf{b}}$ Department of Population Health, London School of Hygiene and Tropical Medicine, Keppel

Street, London, UK

${ }^{\mathbf{c}}$ Health Services and Population Research Department, Institute of Psychiatry, Psychology, and Neuroscience, London, UK

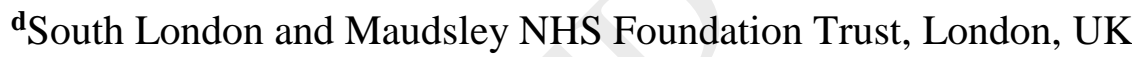

${ }^{\mathbf{e}}$ Harvard University, Cambridge, Massachusetts, Boston, USA

${ }^{\mathbf{f}}$ Faculty of Medicine, McGill University, Montreal, Canada

'Department of Psychology, University of Bath, Bath, UK

hInstitute of Psychiatry and Human Behaviour, Bambolim, Goa, India

$\S_{\text {Joint First Authors }}$

Correspondence: Abhijit Nadkarni, Sangath, H No 451 (168), Bhatkar Waddo, Socorro, Porvorim, Bardez, Goa, India, 403501 abhijit.nadkarni@1shtm.ac.uk 
*Supplementary material can be found by accessing the online version of this paper at http://dx.doi.org and by entering doi:...

\title{
Highlights
}

- Several studies in LMICs use non-recommended AUDIT cut-off scores

- Most such cut-off scores have not undergone psychometric validation

- A range of AUDIT cut-off scores appear to be suitable based on cultural context

\begin{abstract}
Introduction: The World Health Organization's (WHO) Alcohol Use Disorders Identification Test (AUDIT) is used extensively across the world, with cut-off scores recommended by the WHO. We reviewed the use and validity of AUDIT cut-off scores in low- and middle-income countries as cultural contexts are expected to influence the detection of alcohol use disorders. Materials and Methods: The systematic review was guided by an a priori defined protocol consistent with the PRISMA (Preferred Reporting Items for Systematic Reviews and MetaAnalyses) statement. We searched Cochrane library, Medline, EMBASE, PsycINFO, CINAHL, Indmed, LILACS, and AJOL databases using appropriate search terms. We conducted a narrative synthesis of the data.
\end{abstract}

Results: We identified 54 distinct studies that used AUDIT cut-off scores which were not in alignment with those recommended by the WHO. India $(n=10)$, Nigeria $(n=9)$, and Brazil $(n=9)$ produced most of these included studies. Most of the studies $(n=42)$ did not conduct psychometric evaluations of AUDIT cut-off scores. Of the twelve studies which did report psychometric results, a wide range of cut-off scores performed well. In these studies the cut-off 
scores to detect hazardous drinking ranged from $>3$ to $>5$, for harmful drinking from $>5$ to $>16$, and for dependent drinking from $>7$ to $>24$.

Discussion: AUDIT is being widely used in LMICs and non-recommended cut-off scores are considered to be appropriate in these countries. It is important to systematically evaluate the psychometric properties of those cut-off scores to ensure the internal validity of the studies in which they are used.

Keywords: Alcohol Use Disorders Identification Test (AUDIT), Alcohol Use Disorders, Psychometrics, Low- and Middle-Income Countries, Systematic review

\section{Introduction}

The Alcohol Use Disorders Identification Test (AUDIT) was developed by the World Health Organization (WHO) as a tool to screen for alcohol use disorders (AUD) in various populations (Saunders et al., 1993). It is used to detect both AUD (harmful and dependent drinking) and at-risk alcohol consumption (hazardous drinking). This capability is one of its major advantages in comparison to other screening instruments, which generally focus only on harmful and dependent drinking (Gordon, 2006). Since it was first published, the AUDIT has been translated into many different languages and has been validated in different settings (Meneses-Gaya et al., 2009a). Over the years, the AUDIT has also been used extensively in clinical and epidemiological research across the world (Berner et al., 2007).

The 10-item AUDIT assesses three conceptual domains: alcohol intake (items 1-3), dependence (items 4-6), and adverse consequences (items 7-10). The AUDIT is scored by summing the values associated with the various response options, and scores can range from 0 to 
40. A range of cut-off scores for the AUDIT have been proposed to identify AUD. The generally accepted cut-off score of $>8$ provides good sensitivity to detect AUD, but a cut-off score of $>10$ offers better specificity (Babor et al., 2001). Furthermore, lower cut-off scores have been recommended for special populations or for when the focus of the screening is on at-risk alcohol consumption (Reinert and Allen, 2007). The WHO recommends the following scores for categorization of AUD: hazardous drinking (8-15), harmful drinking (16-19), and dependent drinking (>20) (Babor et al., 2001). The AUDIT is intended to assist clinicians to make decisions about management of AUD and any non-validated changes to the recommended cut-off scores could potentially affect the ability of the tool to accurately identify people with AUD. Any resultant changes in the sensitivity or specificity of the AUDIT has the potential of reducing the efficiency and utility of the tool in routine clinical care

Studies from high income countries (HICs) have recommended a range of AUDIT cut-off scores for their settings: >13 for alcohol dependence in France (Gache et al., 2005), >5 for AUD in Germany (Dybek et al., 2006), >3 and >10 for hazardous drinking and AUD respectively in Republic of Korea (Kim et al., 2014), and >10 and >17 respectively for harmful use and dependence in Australia (Degenhardt et al., 2001). The AUDIT has been translated into several languages, but only a few of these translations (e.g. Korean, Chinese, Tibetan) have been adapted to take into account local variations in standard drink sizes or national recommendations regarding safe drinking levels (Babor and Robaina, 2016). An example of such an adaptation is the U.S. AUDIT, in which the first three questions have been adjusted for the standard U.S. drink size (14 grams), the number of response alternatives in questions 1 to 3 have been expanded, and the wording of question 3 has been modified (Higgins-Biddle and Babor, 2018). 
There are a number of issues regarding the use of AUDIT which require further examination. The cultural views of AUD are influenced by prevailing norms in the society and hence there could be a cross-cultural difference in the threshold for the identification of disorders relating to the use of alcohol. A number of core concepts underpinning the diagnosis of AUD have no equivalents in the local languages of various cultures, while other aspects lack cultural applicability because they do not reflect cultural and ethnic norms of drinking (Gureje et al., 1997). An example of the latter is item 10 of the AUDIT questionnaire, which asks about other people expressing concern about one's drinking. In some cultures, comments on others' drinking behavior are very common and are not considered an adequate indicator of pathological drinking behavior (Smit et al., 2006). Furthermore, populations may also vary genetically, resulting in different alcohol tolerances and hence different trajectories to development of AUD (Edenberg, 2007).

Standardized instruments, such as the AUDIT, allow for comparison of findings across cultures and countries. However, standardized instruments that reflect a mainstream culture, when used in disparate cultural groups, also run the risk of measurement errors if the instruments lack cultural relevance. This issue raises several questions about the appropriateness in low- and middle- income countries (LMICs) of the cut-off scores recommended by the WHO, especially considering that these scores are not appropriate even in some HICs, as described above. The aim of this review is to examine the use of non-WHO-recommended AUDIT cut-off scores in LMICs, including the psychometric properties of these cut-off scores.

\section{Materials and Methods}

This systematic review was guided by an a priori defined protocol consistent with the PRISMA (Preferred Reporting Items for Systematic Reviews and Meta-Analyses) statement 
(Moher et al., 2009) and registered on PROSPERO (CRD42016042757). The following electronic databases were searched: Cochrane library, Medline, EMBASE, PsycINFO, Global Health, Cumulative Index to Nursing and Allied Health Literature (CINAHL), Indmed (database of peer reviewed medical journals published from India), Literatura Latino Americana em Ciências da Saúde (LILACS-index of scientific and technical literature of Latin America and the Caribbean), and African Journals OnLine (AJOL- online library of peer-reviewed, Africanpublished scholarly journals).

The search was conducted using appropriate search terms under the following concepts: AUDIT (e.g. AUDIT, Alcohol Use Disorder Identification Test), alcohol use and alcohol use disorders (e.g. alcohol drinking, hazardous drinking), psychometrics and context of use (e.g. validity, reliability, screening), and LMICs (e.g. developing countries, names of all LMICs as classified by the World Bank). The search strategy that we used for Medline is presented in Supplementary Material ${ }^{*}$, and it was adapted as needed to meet the unique requirements of the other databases.

NM conducted the search in June 2016, and NM and MI piloted the eligibility criteria and data extraction tool by applying them to the search returns. Subsequently, SK and AN independently assessed the titles and abstracts of the studies identified through the search of the electronic databases. If the title and abstract did not offer enough information to determine inclusion, the full paper was retrieved to ascertain whether it was eligible for inclusion. SK and AN then discussed their independent selections and arrived at a final list of eligible papers. AN inspected the reference lists of eligible papers and relevant reviews to include additional eligible

\footnotetext{
${ }^{*}$ Supplementary material can be found by accessing the online version of this paper at http://dx.doi.org and by entering doi:...
} 
papers that were not retrieved by the search of the electronic databases. AN also conducted a forward search on Web of Science using the eligible papers to identify studies which might have been missed in the original electronic database search and to identify eligible studies which cited any of the included papers. Finally, AG repeated the search in July 2018 to identify any studies that were published after the original search in 2016.

\subsection{Eligibility Criteria}

There were no restrictions on year of publication, gender, and age of the participants. Only English language publications and studies conducted in LMICs were included. Randomized control trials (RCTs), observational studies, case reports, and case series were included. Qualitative studies and any study which used a non-validated adaptation (i.e. changes made to the original tool but not psychometrically tested) of the AUDIT questionnaire were excluded. Only studies which used AUDIT cut-off scores which were different from those recommended by the WHO, and/or tested the psychometrics of AUDIT cut-off scores which were different from those recommended by the WHO were included.

\subsection{Data Extraction and Analysis}

Following PRISMA guidelines, a record was made of the number of papers retrieved, the number of papers excluded and the reasons for their exclusion, and the number of papers included. A data extraction form was designed for the papers, and included information such as the AUDIT cut-off scores, psychometrics of the cut off score, setting, sample description, study design, control, and results of the included studies. SC and SW independently extracted the data and any disagreements about extracted data were discussed and resolved. AN supervised the data extraction process. Lastly, AG conducted a narrative synthesis of the data by examining the extracted data and identifying common as well as deviant themes across studies. 


\section{Results}

Fifty-seven papers (Table 1) were included in this review by using a multi-step process to identify eligible studies (Figure 1). We identified 722 papers at the end of the electronic database search. After excluding 157 duplicates we were left with 565 unique papers. We screened the abstracts of all these papers and excluded 301 which were not relevant to the aims of our review. We reviewed the full-texts of the remaining 264 papers and excluded 207 for the following reasons: non-English papers $(n=92)$, used WHO recommended cut-off scores $(n=71)$, full text was inaccessible $(n=23)$, and cut-off scores were not mentioned $(n=21)$. Five papers (Meneses-Gaya et al., 2010a; Meneses-Gaya et al., 2010b; Nadkarni et al., 2017a; Nadkarni et al., 2017b; Patel et al., 2014) were derived from only two studies, and as such will be considered as only two studies for the remainder of the analysis i.e. 54 distinct studies were included in this review. Most of these 54 studies were conducted in Africa $(n=21)$, followed by Asia $(n=17)$ and South America $(\mathrm{n}=13)$; the remainder were conducted in Europe $(\mathrm{n}=2)$ and Mexico $(\mathrm{n}=1)$. India $(\mathrm{n}=10)$, Nigeria $(\mathrm{n}=9)$, and Brazil $(\mathrm{n}=9)$ produced most of the included studies.

Most studies were conducted in community settings $(\mathrm{n}=26)$, followed by tertiary care facilities $(\mathrm{n}=12)$. Communities included, but were not limited to, schools/colleges (e.g. Domingues and Domingues, 2011; Strunin et al., 2013), urban areas (e.g. Ansoleaga et al., 2013; Chen et al., 2013), households (e.g. Kanyoni et al., 2015), slums (e.g. Ghosh et al., 2012), and villages (e.g. Jonas et al., 2014). Tertiary care facilities included, among others, infectious disease hospital units (e.g. Goar et al., 2011) and specialized HIV clinics (Farley et al., 2010; Luna et al., 2014; Parry et al., 2014). The rest were conducted in primary care $(\mathrm{n}=7)$ or secondary care $(\mathrm{n}=12)$ facilities such as primary health care clinics (e.g. Luitel et al., 2018) and outpatient clinics (e.g. Yee et al., 2014), respectively. Some studies combined settings, as in the case of one 
study which recruited participants from both the community (throughout St. Petersburg) and tertiary care facilities (i.e. addiction care sites) (e.g. Lasser et al., 2018). The majority of studies were cross-sectional $(n=48)$; the remainder were cohort studies $(n=3)$ and randomized controlled trials $(n=3)$.

Sample sizes in the studies ranged from 52 participants (Yee et al., 2014) to 12,781 (Ansoleaga et al., 2013). The median sample size was 337 participants. Most studies had samples of both men and women ( $\mathrm{n}=38)$, but 12 studies investigated only one gender: four with allfemale samples (Chen et al., 2013; May et al., 2018; Nöthling et al., 2013; Vythilingum et al., 2012) and eight with all-male samples (Dasgupta et al., 2013; Endsley et al., 2017; Ghosh et al., 2012; Ludford et al., 2013; Martins et al., 2012; Nadkarni et al., 2017a; Nadkarni et al., 2017b; Nayak et al., 2009; Pal et al., 2007; Patel et al., 2014). Four studies did not describe the gender distribution of their samples (Farley et al., 2010; Guo et al., 2008; Parry et al., 2014; Pinheiro et al., 2006).

The majority of the included studies did not measure psychometric properties of the AUDIT cut-off scores that were used ( $n=42$ studies, $77.8 \%$ ) (Table 2). All of these studies used at least one cut-off score that did not align with the WHO's recommendations, but these modified cut-off scores were not tested for psychometric properties. However, some studies modified their specified cut-off scores according to prior validation studies. For example, one study used cut-off scores of $>8$ to detect "probable drinking problems" and of $>13$ to detect "probable alcohol dependence" (Chen et al., 2013). These scores were consistent with a prior validation study (Saunders et al., 1993). As demonstrated here, many studies — both those that did and did not use the WHO's recommended cut-off scores-revised the WHO's terminology of AUD categories (hazardous, harmful, and dependent) it was measuring such that it was 
impossible to verify if the scores were used consistently across studies ( $n=8$, e.g. "alcohol use in excess of low risk" (Sau, 2017)). Without psychometric validation and because the included research used such widely different terminology, the AUDIT cut-off scores that these 42 nonvalidation studies used could not be readily evaluated.

Of the 54 distinct studies, 12 were validation studies (Table 3). These 12 studies used a wide range of AUDIT cut-off scores to detect different levels of drinking. Cut-off scores to detect hazardous drinking ranged from $>3$ to $>5$, for harmful drinking from $>5$ to $>16$, and for dependent drinking from $>7$ to $>24$. Nearly all of these studies used at least one cut-off score lower than those recommended by the WHO $(n=10)$. Additionally, one-third of these validation studies recommended different cut-off scores based on gender $(n=4)$. Many of these validation studies $(n=8)$, much like the studies that did not conduct validation of the cut-off scores they used, replaced the WHO's terminology for AUD categories with other terminology (e.g. "alcohol abuse," "alcohol use disorder," "potential alcohol abuse," and "binge drinking"). This nonstandard terminology again precluded subsequent synthesis of these results. Only some of the validation studies clearly defined what a "standard drink" was for their study. This varied greatly- 10 grams ethanol (Pradhan et al., 2012; Guo et al., 2008), 13 grams ethanol (Santis et al., 2009), and 13.5 grams ethanol (Adewuya, 2005). Few studies explicitly described a standard drink in terms of local alcohol beverages (e.g. one standard drink as 300-330 ml of self-brewed highland barley wine, Guo et al., 2008; Endsley et al., 2017).

Of the four studies which included both psychometric data and standard terminology, no cut-off scores clearly outperformed the rest. For hazardous drinking, all of the included cut-off scores ( $>3$ to $>5$ yielded psychometric results which ranged from $93.5 \%$ to $96.2 \%$ for sensitivity, from $63.3 \%$ to $91.5 \%$ for specificity, from $58.1 \%$ to $89.3 \%$ for Positive Predictive Value [PPV], 
and from $94.8 \%$ to $96.9 \%$ for Negative Predictive Value [NPV]). For harmful drinking, a cut-off score of $>7$ or $>8$ in two studies-Adewuya (2005) and Tsai et al. (2005), respectively- displayed better psychometric properties (90.0\% sensitivity, $86.2 \%$ specificity, $47.4 \%$ PPV, $98.4 \%$ NPV in Adewuya (2005); 96\% sensitivity, 85\% specificity, 85\% PPV, 96\% NPV in Tsai et al., (2005)) than a lower cut-off score of $>5$ (75\% sensitivity, $64.5 \%$ specificity, $45 \%$ PPV, $87 \%$ NPV; Santis et al. (2009)). One study from India found that an even higher score of $>16$ for harmful drinking yielded the highest psychometric results within the study $(85.3 \%$ sensitivity, $89.4 \%$ specificity; Pal et al. (2004)). Dependent drinking was measured with the widest range of cut-off scores $(>7$ to $>24$ ), and all but a cut-off score of $>7$ (with sensitivity $63.6 \%$, specificity $75 \%$, PPV $46.7 \%$, NPV 85.7\%; Santis et al. (2009)) yielded generally high psychometric properties (sensitivity ranged from 81 to $100 \%$, specificity from 28.6 to $94.1 \%$, PPV from 20 to $89.3 \%$, and NPV from 85.7 to $100 \%$ ). Overall, a wide range of AUDIT cut-off scores performed well across studies. Notably, many of these included cut-off scores were lower than those recommended by the WHO. Although the validation studies used a wide variety of assessment instruments to generate reference diagnoses for the studies, almost all of those were standardized tools. This was a particular strength of those studies as accurate identification of the reference diagnosis is of critical importance in validation studies. For more details on the psychometric properties associated with different AUDIT cut-off scores, please refer to Table 3.

\section{Discussion}

Our review aimed to examine the ways in which the AUDIT has been used in LMICs, specifically the use of contextualized cut-off scores. Our search yielded 57 relevant results with heterogenous study designs, samples, and contexts. 
One major finding was the lack of psychometric data on the AUDIT cut-off scores used in most of the studies. Even though many of these studies cited past studies which validated these cut-off scores, they rarely cited studies that took place in the same socioeconomic and cultural contexts. For example, a study of female sex workers in Guangxi, China (Chen et al., 2013) cited a validation study that took place across many countries (Australia, Bulgaria, Kenya, Mexico, Norway, and the US), but did not include China or even any other Asian country (Saunders et al., 1993). The geographical and cultural diversity of these settings renders such comparisons weak, as prior research has suggested that the same cut-off scores on the AUDIT do not function equally well across cultures or populations (Berner et al., 2007; Cherpitel et al., 2005). Therefore, these cut-off scores, even when previously validated in prior studies, could not be properly evaluated for their applicability and validity in the studies at hand.

One major barrier to synthesizing the data about AUDIT cut-off scores was the diversity of terminology used to describe different categories of AUD. This inconsistent terminology, something that has historically plagued AUD research, was common across many studies, regardless of whether these studies measured psychometrics. Although the WHO recommends cut-off scores that will detect hazardous, harmful, and dependent drinking, many research studies replaced these terms with others such as "low risk" use or "binge drinking". Without the use of standard terminology, it is impossible to determine whether the AUDIT cut-off scores are measuring the same constructs across studies, thereby limiting their cross-comparability.

Our most critical finding is that nearly all the AUDIT cut-off scores reported in these validation studies were lower than those recommended by the WHO. This finding suggests that the original recommendations maximized specificity at the price of sensitivity, and that dropping these cut-off scores further will tend to identify more people at risk of AUD. Only 10 studies 
included in our review used WHO's standardized terminology and examined psychometric data about AUDIT cut-off scores. There was a range of cut-off scores with relatively adequate psychometric properties across these studies, and the variability is most likely a product of the different cultural contexts in which these studies took place. Past research has suggested that the AUDIT must be culturally adapted because of the varying definitions across cultures of standard drinks, hazardous or heavy drinking, genetic differences between cultural groups, and so on (Edenberg, 2007; Smit et al., 2006). One reason for this could be that a tool like the AUDIT cannot be assumed to work in the same way across cultures, given that substance use varies due to varying social expectations and prevailing laws (Gureje et al., 1996). For example, one study included in this review (May et al., 2018) identifies binge drinking on Friday and Saturday nights among women of childbearing age as a drinking pattern common in South Africa, but not necessarily universally. Hence, screening tools might not function in a similar manner given varying drinking patterns. Another example of contextual differences in the constructs around alcohol use is the definition of a standard drink. For example, 8 grams of pure ethanol in the United Kingdom is a standard drink, while it is 14 grams in the United States. These varying definitions likely contribute to the diversity of cut-off scores. The WHO AUDIT handbook itself recommends that the tool's cut-off scores be adjusted according to "national or cultural standards," albeit without further exploring these standards (Meneses-Gaya et al., 2009b) or recommending processes for making the adjustments. Furthermore, this recommendation is not particularly helpful in countries which do not have standard drink measurements or indeed have poorly established cultural norms around drinking behaviours. Thus, our finding that different cut-off scores work well in different cultural contexts is consistent with past literature on the AUDIT. 
Finally, several studies included in this review $(n=9)$ used different AUDIT cut-off scores based on gender. Although WHO recommendations do not explicitly encourage gender-based cut-off scores, addictions literature emphasizes the importance of making these distinctions when using the AUDIT (Aalto et al., 2006). Much as drinking patterns vary across cultures, so too can drinking patterns and their impact vary across genders (Holmila and Raitasalo, 2005). Thus, future studies should continue to examine differences in psychometrics of the AUDIT based on gender. Existing studies which examine psychometrics but without mixed samples (e.g. Endsley et al. (2017); Nayak et al. (2009)) should be interpreted carefully, as cut-off scores which yield robust psychometric data in samples of only men may not be generalizable to women and vice versa.

Our review was limited by our inclusion criteria. We excluded non-English-language studies and grey literature, which could mean that we did not cover all relevant data. The former limitation may be particularly significant considering that our review focuses on LMICs, which likely produce research in non-English languages.

Our review's major strength lies in its originality: to date, no systematic review has been conducted to comprehensively investigate the way in which the AUDIT has been used and adapted in LMICs. Although such studies exist in high-income countries, these findings cannot be generalized to the LMIC context. LMICs experience a different set of health-related problems and a dearth of health-related resources with which to tackle these problems. Thus, reviews such as this one, which focus exclusively on LMICs, are imperative in supporting contextually informed research.

Our review underscores the large gap in psychometric data regarding AUDIT cut-off scores in LMICs. It highlights the clear need for more rigorous testing of the AUDIT tool across 
cultural contexts and in mixed-gender samples, given how sensitive the tool is to demographic differences. Thus, the AUDIT should preferably be adapted if needed and validated every time it is used in a new context that is not comparable to any previous applications of the tool. These cultural adaptations of the tool are hugely important because without them, alcohol-related issues could be under-reported or mis-reported in LMICs — where these issues are becoming increasingly common and debilitating (Caetano and Laranjeira, 2006). It is only with rigorously validated screening measures that we can develop a fuller picture of the nature of alcohol-related problems in LMICs and begin to help those suffering from these problems. Furthermore, the AUDIT must be evaluated separately by gender and age (e.g. adolescents, elderly), as both these conditions will most likely affect the psychometric properties of the tool.

Our review has highlighted the large gap in research regarding the psychometrics and application of the AUDIT in LMICs. This gap points us to two vital next steps: first, more research must be conducted in LMICs to test the psychometrics of AUDIT cut-off scores in different cultural contexts, as the wide range of results found in this study suggest that the recommended AUDIT cut-off scores are not universally generalizable. Second, standard terminology must be used to describe different levels of drinking (i.e. the WHO's suggestions of hazardous, harmful, and dependent) such that psychometric studies can be more readily compared.

\section{Author Disclosures}

\section{Role of Funding Source}


This work was supported by Grand Challenges Canada [Grant number 0595-04]. The funding agency had no role in the analysis and interpretation of data; in the writing of the manuscript; or in the decision to submit the paper for publication.

\section{Contributors}

Each author of the manuscript has contributed to one or more of the following: design, leadership, conceptualization of the paper, drafting the search strategy, running the search, screening the search returns, data extraction, synthesis of data, and writing up of the findings; and commenting on the drafts of the manuscript. All authors have read and approved the final manuscript.

\section{Contributors}

This is to declare that each author of the marluscript has contributed as outlined below. Abhijil Nadknrni conceived and led the study, conceived the paper, screened the search returns and wrote the introduction and methods, and commented on the first draft and subsequent revisions. Alison Garter synthesized the data and wrote the first draft and subsequent revisions of the results and discussion, Shaina Costa and Sheena Wood extracted the data and commented on the draft manuscript. Sonali Kumar screened the search returns in parallel with Abhij Nadkami, and commented on the draft manuscript. Natahalie MacKinnon and Mariam Ibrahim piloted the search strategy, eligibility criteria and data extract on tool. Both commented on the draft manuscript. Richard Velleman, Godwin Fernandes, Urvita Bhatia, Benedict Weobong, and Anil Rane contributed to the review protocol, and commented on the draft of the manuscript. All authors read and approved the final manuscript.

\section{Conflict of Interest}

No conflict declared

\section{Acknowledgements}


None 


\section{References}

Aalto, M., Tuunanen, M., Sillanaukee, P., Seppä, K., 2006. Effectiveness of structured questionnaires for screening heavy drinking in middle-aged women. Alcohol. Clin. Exp. Res. 30, 1884-1888.

Abayomi, O., Onifade, P.O., Adelufosi, A.O., Akinhanmi, A.O., 2013. Psychosocial correlates of hazardous alcohol use among undergraduates in southwestern Nigeria. Gen. Hosp. Psychiatry 35, 320-324.

Adams, S., Ataya, A.F., Attwood, A.S., Munafò, M.R., 2013. Effects of alcohol on disinhibition towards alcohol-related cues. Drug Alcohol Depend. 127, 137-142.

Adewuya, A.O., 2005. Validation of the alcohol use disorders identification test (AUDIT) as a screening tool for alcohol-related problems among Nigerian university students. Alcohol Alcohol. 40, 575-577.

Ansoleaga, E., Montaño, R., Vézina, M., 2013. Psychosocial risk at work and hazardous alcohol consumption among Chile's working adults. Can. J. Public Health 104, 502-508.

Babor, T.F., Higgins-Biddle, J.C., Saunders, J.B., Monteiro, M.G., World Health Organization, 2001. AUDIT: The alcohol use disorders identification test: Guidelines for use in primary health care. Available at:

http://apps.who.int/iris/bitstream/handle/10665/67205/WHO_MSD_MSB_01.6a.pdf?seq uence $=1$

Babor, T.F., Robaina, K., 2016. The Alcohol Use Disorders Identification Test (AUDIT): A review of graded severity algorithms and national adaptations. Int. J. Alcohol Drug. Res. $5,17-24$. 
Berner, M.M., Kriston, L., Bentele, M., Härter, M., 2007. The alcohol use disorders identification test for detecting at-risk drinking: a systematic review and meta-analysis. J. Stud. Alcohol Drugs 68, 461-473.

Blair, A.H., Pearce, M.E., Katamba, A., Malamba, S.S., Muyinda, H., Schechter, M.T., Spittal, P.M., 2017. The Alcohol Use Disorders Identification Test (AUDIT): Exploring the factor structure and cutoff thresholds in a representative post-conflict population in Northern Uganda. Alcohol Alcohol. 52, 318-327.

Brisibe, S., Ordinioha, B., Dienye, P.O., 2011. Intersection between alcohol abuse and intimate partner's violence in a rural Ijaw community in Bayelsa State, South-South Nigeria. J. Interpers. Violence 27, 513-522.

Caetano, R., Laranjeira, R., 2006. A 'perfect storm' in developing countries: economic growth and the alcohol industry. Addiction 101, 149-152.

Chen, Y., Li, X., Zhang, C., Hong, Y., Zhou, Y., Liu, W., 2013. Alcohol use and sexual risks: use of the Alcohol Use Disorders Identification Test (AUDIT) among female sex workers in China. Health Care Women Int. 34, 122-138.

Cherpitel, C.J., Ye, Y., Moskalewicz, J., Swiatkiewicz, G., 2005. Screening for alcohol problems in two emergency service samples in Poland: comparison of the RAPS4, CAGE and AUDIT. Drug Alcohol Depend. 80, 201-207.

Chishinga, N., Kinyanda, E., Weiss, H.A., Patel, V., Ayles, H., Seedat, S., 2011. Validation of brief screening tools for depressive and alcohol use disorders among TB and HIV patients in primary care in Zambia. BMC Psychiatry 11, 75. 
D'Costa, G., Nazareth, I., Naik, D., Vaidya, R., Levy, G., Patel, V., King, M., 2007. Harmful alcohol use in Goa, India, and its associations with violence: a study in primary care. Alcohol Alcohol. 42, 131-137.

Dasgupta, A., Battala, M., Saggurti, N., Nair, S., Naik, D.D., Silverman, J.G., Balaiah, D., Raj, A., 2013. Local social support mitigates depression among women contending with spousal violence and husband's risky drinking in Mumbai slum communities. J. Affect. Disord. 145, 126-129.

Degenhardt, L.J., Conigrave, K.M., Wutzke, S.E., Saunders, J.B., 2001. The validity of an Australian modification of the AUDIT questionnaire. Drug Alcohol Rev. 20, 143-154.

Domingues, R.B., Domingues, S.A., 2011. Headache is associated with lower alcohol consumption among medical students. Arq. Neuropsiquiatr. 69, 620-623.

Dybek, I., Bischof, G., Grothues, J., Reinhardt, S., Meyer, C., Hapke, U., John, U., Broocks, A., Hohagen, F., Rumpf, H.J., 2006. The reliability and validity of the Alcohol Use Disorders Identification Test (AUDIT) in a German general practice population sample. J. Stud. Alcohol 67, 473-481.

Edenberg, H.J., 2007. The genetics of alcohol metabolism: role of alcohol dehydrogenase and aldehyde dehydrogenase variants. Alcohol Res. Health 30, 5-13.

Endsley, P., Weobong, B., Nadkarni, A., 2017. Psychometric properties of the AUDIT among men in Goa, India. Asian J. Psychiatr. 29, 54-58.

Farley, J., Miller, E., Zamani, A., Tepper, V., Morris, C., Oyegunle, M., Lin, M., Charurat, M., Blattner, W., 2010. Screening for hazardous alcohol use and depressive symptomatology among HIV-infected patients in Nigeria: prevalence, predictors, and association with adherence. J. Int. Assoc. Physicians AIDS Care (Chic) 9, 218-226. 
Gache, P., Michaud, P., Landry, U., Accietto, C., Arfaoui, S., Wenger, O., Daeppen, J.B., 2005. The Alcohol Use Disorders Identification Test (AUDIT) as a screening tool for excessive drinking in primary care: reliability and validity of a French version. Alcohol Clin. Exp. Res. 29, 2001-2007.

Ghosh, S., Samanta, A., Mukherjee, S., 2012. Patterns of alcohol consumption among male adults at a slum in Kolkata, India. J. Health Popul. Nutr. 30, 73-81.

Goar, S., Audu, M., Dochalson, E., Agbir, T., 2011. Prevalence and socio-demographic correlates of alcohol use disorders among HIV patients. Afr. J. Drug Alcohol Stud. 10,4147

Gordon, A.J., 2006. Screening the drinking: Identifying problem alcohol consumption in primary care settings. Advanced Studies in Medicine 6, 137-147.

Goudriaan, A. E., Grekin, E. R., Sher, K. J., 2007. Decision making and binge drinking: a longitudinal study. Alcohol. Clin. Exp. Res. 31, 928-938. doi:10.1111/j.15300277.2007.00378.x

Guo, W., Lanzi, G., Luobu, O., Ma, X., Zhen, P., Ji, Y., Wei, G., Wang, Z., Deng, W., Zhuoma, B., Wang, Y., Shi, X., Yan, C., Liu, X., Collier, D.A., Ball, D., Li, T., 2008. An epidemiological survey of alcohol use disorders in a Tibetan population. Psychiatry Res. $159,56-66$.

Gureje, O., Obikoya, B., Ikuesan, B.A., 1992. Alcohol abuse and dependence in an urban primary care clinic in Nigeria. Drug Alcohol Depend. 30, 163-167.

Gureje, O., Vazquez-Barquero, J.L., Janca, A., 1996. Comparisons of alcohol and other drugs: experience from the WHO Collaborative Cross-Cultural Applicability Research (CAR) Study. Addiction 91, 1529-1538. 
Gureje, O., Mavreas, V., Vazquez-Barquero, J.L., Janca, A., 1997. Problems related to alcohol use: A cross-cultural perspective. Cult. Med. Psychiatry 21, 199-211.

Herrera, M., Konda, K., Leon, S., Wong, P., Brown, B., Caceres, C., Klausner, J., 2015. Characterising the epidemiology of active hepatitis b virus infection among high-risk men who have sex with men and transgender women in Lima, Peru. Sex. Transm. Infect. 91, A180-A181.

Higgins-Biddle, J.C., Babor, T.F., 2018. A review of the Alcohol Use Disorders Identification Test (AUDIT), AUDIT-C, and US-AUDIT for screening in the United States: Past issues and future directions. Am. J. Drug Alcohol Abuse 44, 578-586.

Holmila, M., Raitasalo, K., 2005. Gender differences in drinking: why do they still exist? Addiction 100, 1763-1769.

Issa, B.A., Yussuf, A.D., Abiodun, O.A., Olanrewaju, G.T., Kuranga, T.O., 2012. Hazardous alcohol use among doctors in a Nigerian tertiary hospital. West Afr. J. Med. 31, 97-101.

Jonas, J.B., Nangia, V., Rietschel, M., Paul, T., Behere, P., Panda-Jonas, S., 2014. Prevalence of depression, suicidal ideation, alcohol intake and nicotine consumption in rural Central India. The Central India Eye and Medical Study. PLoS One 9, e113550.

Kanyoni, M., Gishoma, D., Ndahindwa, V., 2015. Prevalence of psychoactive substance use among youth in Rwanda. BMC Res. Notes 8, 190.

Kim, C.G., Kim, J.S., Jung, J.G., Kim, S.S., Yoon, S.J., Suh, H.S., 2014. Reliability and validity of Alcohol Use Disorder dentification Test-Korean Revised Version for screening at-risk drinking and alcohol use disorders. Korean J. Fam. Med. 35, 2-10.

Lasser, K.E., Lunze, K., Cheng, D.M., Blokhina, E., Walley, A.Y., Tindle, H.A., Quinn, E., Gnatienko, N., Krupitsky, E., Samet, J.H., 2018. Depression and smoking characteristics 
among HIV-positive smokers in Russia: A cross-sectional study. PLoS One 13, e0189207.

Ludford, K.T., Vagenas, P., Lama, J.R., Peinado, J., Gonzales, P., Leiva, R., Pun, M., Sanchez, J., Altice, F.L., Group, P.H.S.S.W., 2013. Screening for drug and alcohol use disorders and their association with HIV-related sexual risk behaviors among men who have sex with men in Peru. PLoS One 8, e69966.

Luitel, N.P., Baron, E.C., Kohrt, B.A., Komproe, I.H., Jordans, M.J.D., 2018. Prevalence and correlates of depression and alcohol use disorder among adults attending primary health care services in Nepal: a cross sectional study. BMC Health Serv. Res. 18, 215.

Luitel, N.P., Jordans, M.J.D., Kohrt, B.A., Rathod, S.D., Komproe, I.H., 2017. Treatment gap and barriers for mental health care: A cross-sectional community survey in Nepal. PLoS One 12 , e0183223.

Luna, J., Gurgel, W., Matos, K., Barros, E., Ribeiro, C., Matos e Souza, F., Study Group, A., 2014. The influence of Alcohol Use Disorders on sex and mood in an HIV infected population in the State of Ceará, Northeastern Brazil. J. AIDS Clin. Res. 5, 285.

Machado, D.e.A., Silva, G.F., Torres, A.R., Cerqueira, A.T., 2014. Depressive symptoms and harmful alcohol use in hepatitis C patients: prevalence and correlates. Rev. Soc. Bras. Med. Trop. 47, 149-157.

Malbergier, A., Amaral, R.A., Cardoso, L.D., 2015. Alcohol dependence and CD4 cell count: is there a relationship? AIDS Care 27, 54-58.

Martins, M.E., Ribeiro, L.C., Feital, T.J., Baracho, R.A., Ribeiro, M.S., 2012. [Religiousspiritual coping and the consumption of alcoholic beverages in male patients with liver disease]. Rev. Esc. Enferm. USP 46, 1340-1347. 
May, P.A., Hasken, J.M., De Vries, M.M., Marais, A.S., Stegall, J.M., Marsden, D., Parry, C.D.H., Seedat, S., Tabachnick, B., 2018. A utilitarian comparison of two alcohol use biomarkers with self-reported drinking history collected in antenatal clinics. Reprod. Toxicol. 77, 25-32.

Meneses-Gaya, C., Crippa, J.A., Zuardi, A.W., Loureiro, S.R., Hallak, J.E., Trzesniak, C., Machado de Sousa, J.P., Chagas, M.H., Souza, R.M., Martín-Santos, R., 2010a. The fast alcohol screening test (FAST) is as good as the AUDIT to screen alcohol use disorders. Subst. Use Misuse 45, 1542-1557.

Meneses-Gaya, C., Zuardi, A., Loureiro, S., Crippa, J., 2009a. Alcohol Use Disorders Identification Test (AUDIT): an updated systematic review of psychometric properties. Psychol. Neurosci. 2, 83-97.

Meneses-Gaya, C., Zuardi, A.W., Loureiro, S.R., Hallak, J.E., Trzesniak, C., de Azevedo Marques, J.M., Machado-de-Sousa, J.P., Chagas, M.H., Souza, R.M., Crippa, J.A., 2010b. Is the full version of the AUDIT really necessary? Study of the validity and internal construct of its abbreviated versions. Alcohol. Clin. Exp. Res. 34, 1417-1424.

Meneses-Gaya, C.d., Zuardi, A.W., Loureiro, S.R., Crippa, J.A.S., 2009b. Alcohol Use Disorders Identification Test (AUDIT): an updated systematic review of psychometric properties. Psychol. Neurosci. 2, 83-97.

Moher, D., Liberati, A., Tetzlaff, J., Altman, D.G., 2009. Preferred reporting items for systematic reviews and meta-analyses: the PRISMA statement. Ann. Intern. Med. 151, 264-269.

Morilha, A., Karagulian, S., Lotufo, P.A., Santos, I.S., Benseñor, I.M., Goulart, A.C., 2015. PostAcute Coronary Syndrome Alcohol Abuse: Prospective Evaluation in the ERICO Study. Arq. Bras. Cardiol. 104, 457-467. 
Nadkarni, A., Weiss, H.A., Weobong, B., McDaid, D., Singla, D.R., Park, A.L., Bhat, B., Katti, B., McCambridge, J., Murthy, P., King, M., Wilson, G.T., Kirkwood, B., Fairburn, C.G., Velleman, R., Patel, V., 2017a. Sustained effectiveness and cost-effectiveness of Counselling for Alcohol Problems, a brief psychological treatment for harmful drinking in men, delivered by lay counsellors in primary care: 12-month follow-up of a randomised controlled trial. PLoS Med 14, e1002386.

Nadkarni, A., Weobong, B., Weiss, H.A., McCambridge, J., Bhat, B., Katti, B., Murthy, P., King, M., McDaid, D., Park, A.L., Wilson, G.T., Kirkwood, B., Fairburn, C.G., Velleman, R., Patel, V., 2017b. Counselling for Alcohol Problems (CAP), a lay counsellor-delivered brief psychological treatment for harmful drinking in men, in primary care in India: a randomised controlled trial. Lancet 389, 186-195.

Nakhli, Hassini, R., Nasr, S., Ali, B., 2011. Factors associated with alcoholic behaviour in university nurse students. Eur. Neuropsychopharmacol. 21, s566.

Nayak, M.B., Bond, J.C., Cherpitel, C., Patel, V., Greenfield, T.K., 2009. Detecting alcoholrelated problems in developing countries: a comparison of 2 screening measures in India. Alcohol. Clin. Exp. Res. 33, 2057-2066.

Ndetei, D.M., Khasakhala, L.I., Ongecha-Owuor, F.A., Kuria, M.W., Mutiso, V., Kokonya, D.A., 2009. Prevalence of substance abuse among patients in general medical facilities in Kenya. Subst. Abus. 30, 182-190.

Nöthling, Martin, C., Laughton, B., Cotton, M., Seedat, S., 2013. Maternal post-traumatic stress disorder, depression and alcohol dependence and child behaviour outcomes in motherchild dyads infected with HIV: A longitudinal study. BMJ Open 3, e003638. 
Obadeji, A., Oluwole, L.O., Dada, M.U., Adegoke, B.O., 2015. Hazardous alcohol use among doctors in a Tertiary Health Center. Ind. Psychiatry J. 24, 59-63.

Olisah, VO, Adekeye, O., Sheich, T., Yusuf, A., 2009. Alcohol-related problems and high risk sexual behaviour in patients with HIV/ AIDS attending medical clinic in a Nigerian University teaching hospital. Afr. J. Drug Alcohol Stud. 8,17-22.

Pal, H.R., Jena, R., Yadav, D., 2004. Validation of the Alcohol Use Disorders Identification Test (AUDIT) in urban community outreach and de-addiction center samples in north India. J. Stud. Alcohol 65, 794-800.

Pal, H.R., Yadav, D., Mehta, S., Mohan, I., 2007. A comparison of brief intervention versus simple advice for alcohol use disorders in a North India community-based sample followed for 3 months. Alcohol Alcohol. 42, 328-332.

Parry, CD, Morojele, N., Myers, B., Kekwaletswe, C., Manda, S., Sorsdahl, K., Shuper, P., 2014. Efficacy of an alcohol-focused intervention for improving adherence to antiretroviral therapy (ART) and HIV treatment outcomes - a randomised controlled trial protocol. BMC Infectious Diseases 14, 500.

Patel, V., Weobong, B., Nadkarni, A., Weiss, H.A., Anand, A., Naik, S., Bhat, B., Pereira, J., Araya, R., Dimidjian, S., Hollon, S.D., King, M., McCambridge, J., McDaid, D., Murthy, P., Velleman, R., Fairburn, C.G., Kirkwood, B., 2014. The effectiveness and costeffectiveness of lay counsellor-delivered psychological treatments for harmful and dependent drinking and moderate to severe depression in primary care in India: PREMIUM study protocol for randomized controlled trials. Trials 15, 101. 
Pinheiro, R.T., Magalhães, P.V., Horta, B.L., Pinheiro, K.A., da Silva, R.A., Pinto, R.H., 2006. Is paternal postpartum depression associated with maternal postpartum depression? Population-based study in Brazil. Acta Psychiatr. Scand. 113, 230-232.

Pradhan, B., Chappuis, F., Baral, D., Karki, P., Rijal, S., Hadengue, A., Gache, P., 2012. The alcohol use disorders identification test (AUDIT): validation of a Nepali version for the detection of alcohol use disorders and hazardous drinking in medical settings. Subst. Abuse Treat. Prev. Policy 7, 42.

Reinert, D.F., Allen, J.P., 2007. The alcohol use disorders identification test: an update of research findings. Alcohol. Clin. Exp. Res. 31, 185-199.

Santis, R., Garmendia, M.L., Acuña, G., Alvarado, M.E., Arteaga, O., 2009. The Alcohol Use Disorders Identification Test (AUDIT) as a screening instrument for adolescents. Drug Alcohol Depend. 103, 155-158.

Sau, A., 2017. AUDIT (Alcohol Use Disorders Identification Test) to estimate the pattern and correlates of alcohol consumption among the adult population of West Bengal, India: A community based cross-sectional study. J. Clin. Diagn. Res. 11, LC01-LC04.

Saunders, J.B., Aasland, O.G., Babor, T.F., de la Fuente, J.R., Grant, M., 1993. Development of the Alcohol Use Disorders Identification Test (AUDIT): WHO Collaborative Project on Early Detection of Persons with Harmful Alcohol Consumption--II. Addiction 88, 791804.

Sekulic, D., Ostojic, M., Ostojic, Z., Hajdarevic, B., Ostojic, L., 2012. Substance abuse prevalence and its relation to scholastic achievement and sport factors: an analysis among adolescents of the Herzegovina-Neretva Canton in Bosnia and Herzegovina. BMC Public Health 12, 274. 
Simbayi, L.C., Kalichman, S.C., Cain, D., Cherry, C., Jooste, S., Mathiti, V., 2006. Alcohol and risks for HIV/AIDS among sexually transmitted infection clinic patients in Cape Town, South Africa. Subst. Abus. 27, 37-43.

Simbayi, L.C., Kalichman, S.C., Jooste, S., Mathiti, V., Cain, D., Cherry, C., 2004. Alcohol use and sexual risks for HIV infection among men and women receiving sexually transmitted infection clinic services in Cape Town, South Africa. J. Stud. Alcohol 65, 434-442.

Smit, J., van den Berg, C.E., Bekker, L.G., Seedat, S., Stein, D.J., 2006. Translation and crosscultural adaptation of a mental health battery in an African setting. Afr. Health Sci. 6, 215-222.

Strunin, L., Díaz Martínez, A., Díaz-Martínez, L.R., Heeren, T., Kuranz, S., Winter, M., Hernández-Ávila, C.A., Fernández-Varela, H., Solís-Torres, C., 2013. Parental monitoring and alcohol use among Mexican students. Addict. Behav. 38, 2601-2606.

Tsai, M.C., Tsai, Y.F., Chen, C.Y., Liu, C.Y., 2005. Alcohol Use Disorders Identification Test (AUDIT): establishment of cut-off scores in a hospitalized Chinese population. Alcohol. Clin. Exp. Res. 29, 53-57.

Vythilingum, B., Roos, A., Faure, S.C., Geerts, L., Stein, D.J., 2012. Risk factors for substance use in pregnant women in South Africa. S. Afr. Med. J. 102, 851-854.

Yee, A., Adlan, A., Rashid, R., Habil, H., Kamali, K., 2014. Validation of the alcohol use disorders identification test (AUDIT) - Bahasa Malaysia version among a group of alcohol users. J. Subst. Use 20, 229-233.

Zucoloto, M., Cioffi, D., Campos, J., 2013. Effectiveness of different methods for the detection of binge drinking in dentistry students. SMAD, Rev. Eletrônica Saúde Mental Álcool Drog. 9, 129-135. 


\section{Figure Legend}

Fig 1: Flow diagram of process leading to selection of papers for the review.

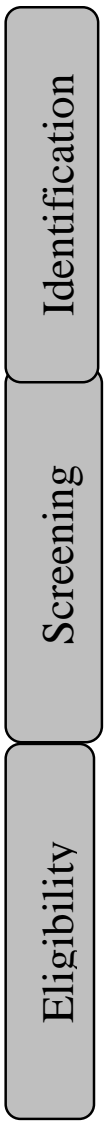

Records identified through database searching

$(\mathrm{n}=722)$
Additional records identified through other sources

$(\mathrm{n}=0)$

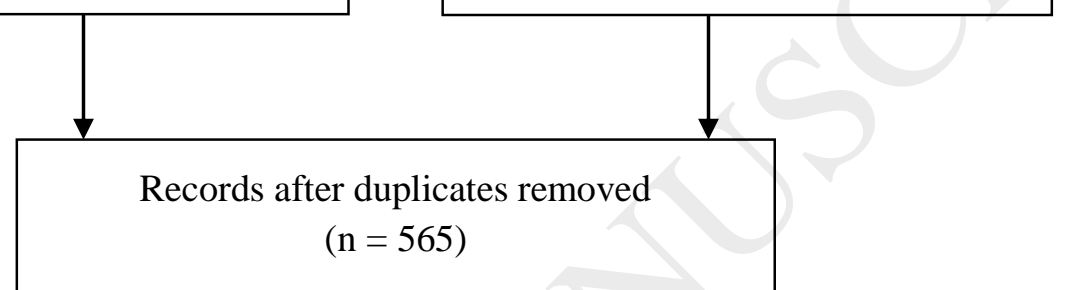

Records excluded as studies not relevant to aims of the review

$$
(\mathrm{n}=301)
$$

Full-text articles excluded

Full text not published in

Full-text articles assessed for eligibility

$$
(\mathrm{n}=264)
$$

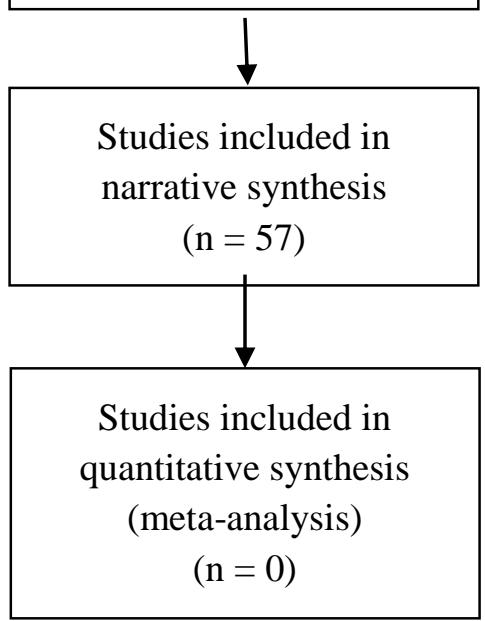

\section{English}

$(n=92)$; Used or recommended $\mathrm{WHO}$ scores $(n=71)$; Full text inaccessible $(n=23)$; No mention of cut-off scores

$$
(n=21)
$$


Table 1: Studies included in the systematic review 


\begin{tabular}{|c|c|c|c|c|c|}
\hline $\begin{array}{l}\text { Author } \\
\text { (Year) }\end{array}$ & Country & $\mathbf{N}$ & Sample & Setting & $\begin{array}{l}\text { Study } \\
\text { design }\end{array}$ \\
\hline Blair (2017) & Uganda & 1720 & $\begin{array}{l}\mathrm{M} 756(44.1 \%) ; \mathrm{F} \\
957 ; \text { age range } 13-52, \\
\text { median age } 27\end{array}$ & Community & Cohort \\
\hline $\begin{array}{l}\text { Kanyoni } \\
(2015)\end{array}$ & Rwanda & 2479 & $\begin{array}{l}\text { Youth (14-35 years); } \\
\text { M 1388 (56.0\%); F } \\
\text { 1091; A } 23.2 \text { years }\end{array}$ & Community & $\begin{array}{l}\text { Cross- } \\
\text { sectional }\end{array}$ \\
\hline $\begin{array}{l}\text { Abayomi } \\
(2013)\end{array}$ & Nigeria & 443 & $\begin{array}{l}\text { Male }(\mathrm{M}) \\
(65.7 \%) ; \text { Female }(\mathrm{F}) \\
\text { 152; Mean age }(\mathrm{A}) 21 \\
\text { (Range } 14-28) \text { years }\end{array}$ & $\begin{array}{l}\text { Community } \\
\text { (University) }\end{array}$ & $\begin{array}{l}\text { Cross- } \\
\text { sectional }\end{array}$ \\
\hline $\begin{array}{l}\text { Adewuya } \\
(2005)\end{array}$ & Nigeria & 248 & $\begin{array}{l}\text { M } 181(73.0 \%) ; \text { F } 67 ; \\
\text { A } 22.5 \text { years }\end{array}$ & $\begin{array}{l}\text { Community } \\
\text { (University) }\end{array}$ & $\begin{array}{l}\text { Cross- } \\
\text { sectional }\end{array}$ \\
\hline $\begin{array}{l}\text { Brisibe } \\
(2011)\end{array}$ & Nigeria & 322 & $\begin{array}{l}\text { M } 166(51.6 \%) ; \mathrm{F} \\
156 ; \mathrm{A} 41.4\end{array}$ & Community & $\begin{array}{l}\text { Cross- } \\
\text { sectional }\end{array}$ \\
\hline Farley (2010) & Nigeria & 399 & $\begin{array}{l}\text { HIV-infected adults in } \\
\text { a HIV care program }\end{array}$ & Tertiary care & $\begin{array}{l}\text { Cross- } \\
\text { sectional }\end{array}$ \\
\hline Goar (2011) & Nigeria & 160 & $\begin{array}{l}\text { Patients being treated } \\
\text { for HIV/AIDS at an } \\
\text { infectious disease unit } \\
\text { of hospital in a major } \\
\text { city; M } 57 \text { ( } 35.6 \%) \text {; F } \\
\text { 103; A } 35.6 \text { years }\end{array}$ & Tertiary care & $\begin{array}{l}\text { Cross- } \\
\text { sectional }\end{array}$ \\
\hline Gureje (1992) & Nigeria & $\begin{array}{l}787 \quad \text { (Stage } \\
1) ; \quad 214 \\
(\text { Stage }\end{array}$ & $\begin{array}{l}\text { Patients at outpatient } \\
\text { clinic, Stage 1: M } 386 \\
(49 \%) \text {; F 401; Stage 2: } \\
\text { M } 107(50 \%) ; \text { F } 107\end{array}$ & $\begin{array}{l}\text { Secondary } \\
\text { care }\end{array}$ & $\begin{array}{l}\text { Cross- } \\
\text { sectional }\end{array}$ \\
\hline Issa (2012) & Nigeria & 241 & $\begin{array}{l}\text { Doctors at a teaching } \\
\text { hospital; } \mathrm{M} \\
(75.5 \%) \text {; F } 59\end{array}$ & Tertiary care & $\begin{array}{l}\text { Cross- } \\
\text { sectional }\end{array}$ \\
\hline $\begin{array}{l}\text { Obadeji } \\
(2015)\end{array}$ & Nigeria & 122 & $\begin{array}{ll}\text { Doctors at a teaching } \\
\text { hospital; } \mathrm{M} & 97 \\
(79.5 \%) ; \text { F } 25 ; & \text { A } \\
\text { 35.65 years } & \end{array}$ & Tertiary care & $\begin{array}{l}\text { Cross- } \\
\text { sectional }\end{array}$ \\
\hline Olisah (2009) & Nigeria & 120 & 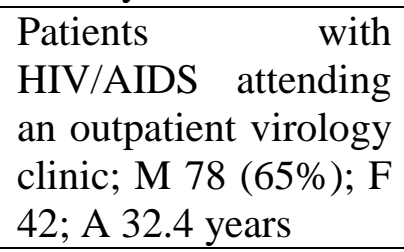 & $\begin{array}{l}\text { Secondary } \\
\text { care }\end{array}$ & $\begin{array}{l}\text { Cross- } \\
\text { sectional }\end{array}$ \\
\hline
\end{tabular}




\begin{tabular}{|c|c|c|c|c|c|}
\hline $\begin{array}{l}\text { Chishinga } \\
(2011)\end{array}$ & Zambia & 649 & $\begin{array}{l}\text { Patients attending } \\
\text { Tuberculosis (TB) or } \\
\text { Anti Retroviral } \\
\text { Treatment } \quad \text { (ART) } \\
\text { clinic; M 363 (55.9\%); } \\
\text { F 286; median age 33 } \\
\text { years }\end{array}$ & Primary care & $\begin{array}{l}\text { Cross- } \\
\text { sectional }\end{array}$ \\
\hline Ndetei (2009) & Kenya & 2770 & $\begin{array}{l}\text { Patients admitted in } \\
\text { general } \\
\text { facilities; } \mathrm{M} \quad 1186 \\
(42.8 \%) ; \mathrm{F} 1584 ; \text { age } \\
\text { range } 18 \text { - } 90 \text { years }\end{array}$ & $\begin{array}{l}\text { Primary, } \\
\text { secondary } \\
\text { and tertiary } \\
\text { care }\end{array}$ & $\begin{array}{l}\text { Cross- } \\
\text { sectional }\end{array}$ \\
\hline Nakhli (2011) & Tunisia & 266 & $\begin{array}{l}\text { University students; } \\
\text { M } 152 \quad(57.1 \%) ; \quad \mathrm{F} \\
114 ; \text { A } 21.2 \text { years }\end{array}$ & Community & Longitudinal \\
\hline $\begin{array}{l}\text { Adams } \\
(2013)\end{array}$ & South Africa & 143 & $\begin{array}{l}\text { M } 70(49.0 \%) ; \text { F 73; A } \\
21.6(18-25) \text { years }\end{array}$ & Community & $\begin{array}{l}\text { Cross- } \\
\text { sectional }\end{array}$ \\
\hline May (2018) & South Africa & 193 & Pregnant women & Primary care & $\begin{array}{l}\text { Cross- } \\
\text { sectional }\end{array}$ \\
\hline $\begin{array}{l}\text { Nothling } \\
(2013)\end{array}$ & South Africa & 70 & $\begin{array}{l}70 \text { mother-child dyads } \\
\text { infected with HIV; A } \\
28.8 \text { (range 16-64) } \\
\text { years }\end{array}$ & Primary care & Cohort \\
\hline Parry (2014) & South Africa & 260 & $\begin{array}{l}\text { HIV positive patients } \\
\text { on ART in ART } \\
\text { clinics; } \\
\text { hazardous/harmful } \\
\text { drinkers }\end{array}$ & Tertiary care & RCT \\
\hline $\begin{array}{l}\text { Simbayi } \\
(2004)\end{array}$ & South Africa & 257 & $\begin{array}{l}\text { Patients receiving } \\
\text { services at STI clinic; } \\
\text { M 149 }(58.0 \%) \text {; F 78; } \\
\text { A 27.5 years }\end{array}$ & $\begin{array}{l}\text { Secondary } \\
\text { care }\end{array}$ & $\begin{array}{l}\text { Cross- } \\
\text { sectional }\end{array}$ \\
\hline $\begin{array}{l}\text { Simbayi } \\
\text { (2006) }\end{array}$ & South Africa & 226 & $\begin{array}{l}\text { Patients receiving } \\
\text { services at STI clinic; } \\
\text { M } 134 \text { (59.3\%); F 92; } \\
\text { Median age } 26 \text { years }\end{array}$ & $\begin{array}{l}\text { Secondary } \\
\text { care }\end{array}$ & $\begin{array}{l}\text { Cross- } \\
\text { sectional }\end{array}$ \\
\hline $\begin{array}{l}\text { Vythilingum } \\
\text { (2012) }\end{array}$ & South Africa & 323 & $\begin{array}{l}\text { Adult women } \\
\text { presenting to their first } \\
\text { antenatal visit at } \\
\text { midwife obstetric } \\
\text { units; A 24.6 years }\end{array}$ & Tertiary care & $\begin{array}{l}\text { Cross- } \\
\text { sectional }\end{array}$ \\
\hline
\end{tabular}




\begin{tabular}{|c|c|c|c|c|c|}
\hline Luitel (2017) & Nepal & 1983 & $\begin{array}{lr}\text { M } 703 \quad(39.9 \%) ; & F \\
1280 ; \text { A } 39.8 \text { years } & \\
\end{array}$ & Community & $\begin{array}{l}\text { Cross- } \\
\text { sectional }\end{array}$ \\
\hline Luitel (2018) & Nepal & 1474 & $\begin{array}{l}\text { M } 504 \quad(34.2 \%) ; \quad F \\
970 ; \text { A } 39.4 \text { years }\end{array}$ & Primary care & $\begin{array}{l}\text { Cross- } \\
\text { sectional }\end{array}$ \\
\hline $\begin{array}{l}\text { Pradhan } \\
(2012)\end{array}$ & Nepal & 1068 & \begin{tabular}{lrr} 
Patients & \multicolumn{2}{r}{ attending } \\
outpatient & department \\
of a & \multicolumn{2}{c}{ university } \\
hospital; & M & 587 \\
$(55 \%) ; \mathrm{F}$ & $481 ;$ A & 47.9 \\
years & & \\
in males and & 47.5 \\
years in females &
\end{tabular} & $\begin{array}{l}\text { Secondary } \\
\text { care }\end{array}$ & $\begin{array}{l}\text { Cross- } \\
\text { sectional }\end{array}$ \\
\hline $\begin{array}{l}\text { Dasgupta } \\
\text { (2013) }\end{array}$ & India & 105 & $\begin{array}{l}\text { M } 105(100 \%) ; \text { A } 30- \\
39 \text { years }(85.7 \%)\end{array}$ & Community & $\begin{array}{l}\text { Cross- } \\
\text { sectional }\end{array}$ \\
\hline $\begin{array}{l}\text { D'Costa } \\
(2007)\end{array}$ & India & 1567 & $\begin{array}{l}\text { Private general } \\
\text { practice attendees; M } \\
338(41 \%) ; \text { F } 597\end{array}$ & Primary care & $\begin{array}{l}\text { Cross- } \\
\text { sectional }\end{array}$ \\
\hline $\begin{array}{l}\text { Endsley } \\
(2017)\end{array}$ & India & 600 & Adult males, A 32.7 & Community & $\begin{array}{l}\text { Cross- } \\
\text { sectional }\end{array}$ \\
\hline Ghosh (2012) & India & 228 & $\begin{array}{l}\text { Males living in slums; } \\
\text { A } 31.4 \text { years }\end{array}$ & Community & $\begin{array}{l}\text { Cross- } \\
\text { sectional }\end{array}$ \\
\hline Jonas (2014) & India & 4711 & $\begin{array}{l}\text { Villagers in rural area; } \\
\text { M } 2191 \quad(46.5 \%) ; \quad F \\
2520 ; \text { A } 49.5(30-95) \\
\text { years }\end{array}$ & Community & $\begin{array}{l}\text { Cross- } \\
\text { sectional }\end{array}$ \\
\hline $\begin{array}{l}\text { Nadkarni } \\
\text { (2017a, } \\
\text { 2017b); Patel } \\
(2014)\end{array}$ & India & 377 & $\begin{array}{l}\text { Adult males }(18-65 \\
\text { years }), \text { A } 42 \text { years }\end{array}$ & Primary care & $\mathrm{RCT}$ \\
\hline Nayak (2009) & India & 1043 & Urban and rural males & Community & $\begin{array}{l}\text { Cross- } \\
\text { sectional }\end{array}$ \\
\hline Pal (2004) & India & 297 & $\begin{array}{l}\text { Patients at either a de- } \\
\text { addiction center or a } \\
\text { community outreach } \\
\text { clinic who had used } \\
\text { alcohol in the past } \\
\text { year, M } 294(99 \%) \text {; F } \\
\text { 3; A 38.1 years }\end{array}$ & $\begin{array}{l}\text { Secondary } \\
\text { and tertiary } \\
\text { care }\end{array}$ & $\begin{array}{l}\text { Cross- } \\
\text { sectional }\end{array}$ \\
\hline Pal (2007) & India & 90 & $\begin{array}{l}\text { Males } r \text { with } \\
\text { problematic alcohol } \\
\text { use; A 29.7 years }\end{array}$ & Community & $\begin{array}{l}\text { Randomised } \\
\text { controlled } \\
\text { trial (RCT) } \\
\end{array}$ \\
\hline Sau (2017) & India & 99 & $\begin{array}{l}\text { M } 54(54.5 \%) ; \mathrm{F} 45 ; \mathrm{A} \\
38.62 \text { years }\end{array}$ & Community & $\begin{array}{l}\text { Cross- } \\
\text { sectional }\end{array}$ \\
\hline Chen (2013) & China & 983 & $\begin{array}{lll}\text { Urban female } & \text { sex } \\
\text { workers; } & \text { A } 24.42 & \end{array}$ & Community & $\begin{array}{l}\text { Cross- } \\
\text { sectional }\end{array}$ \\
\hline
\end{tabular}




\begin{tabular}{|c|c|c|c|c|c|}
\hline Guo (2008) & China & 3171 & A 43.8 years & Community & $\begin{array}{l}\text { Cross- } \\
\text { sectional }\end{array}$ \\
\hline Tsai (2005) & China & 112 & $\begin{array}{l}\text { Inpatients from } \\
\text { gastro-enterology } \\
\text { wards at a medical } \\
\text { research center; M } 78 \\
(69.9 \%) \text { F 34; A } 49.9 \\
\text { years }\end{array}$ & Tertiary care & $\begin{array}{l}\text { Cross- } \\
\text { sectional }\end{array}$ \\
\hline Yee (2014) & Malaysia & 52 & $\begin{array}{l}\text { Psychiatric patients } \\
\text { who consume alcohol, } \\
\text { at psychiatric } \\
\text { outpatient clinics; M } \\
51(98.1 \%) ; \mathrm{F} 1 ; \mathrm{A}= \\
\text { 40.1 years }\end{array}$ & $\begin{array}{l}\text { Secondary } \\
\text { care }\end{array}$ & $\begin{array}{l}\text { Cross- } \\
\text { sectional }\end{array}$ \\
\hline $\begin{array}{l}\text { Sekulic } \\
\text { (2012) }\end{array}$ & $\begin{array}{l}\text { Bosnia and } \\
\text { Herzegovina }\end{array}$ & 1032 & M 435 (42.2\%); F 597 & Community & $\begin{array}{l}\text { Cross- } \\
\text { sectional }\end{array}$ \\
\hline Lasser (2018) & Russia & 351 & $\begin{array}{l}\text { M } 219 \quad(70.9 \%) ; \quad F \\
132 ; \text { A } 33.5 \text { years }\end{array}$ & $\begin{array}{l}\text { Community } \\
\text { and tertiary } \\
\text { care }\end{array}$ & $\begin{array}{l}\text { Cross- } \\
\text { sectional }\end{array}$ \\
\hline $\begin{array}{l}\text { Domingues } \\
\text { (2011) }\end{array}$ & Brazil & 398 & $\begin{array}{l}\text { Medical students; M } \\
174(43.7 \%) ; \mathrm{F} 224 ; \mathrm{A} \\
20.7 \text { years }\end{array}$ & Community & $\begin{array}{l}\text { Cross- } \\
\text { sectional }\end{array}$ \\
\hline Luna (2014) & Brazil & 200 & $\begin{array}{l}\text { HIV-infected patients } \\
\text { in a specialized clinic } \\
\text { for HIV care; M } 133 \\
(66.5 \%) \text { F }(67) ; \quad \text { A } \\
37.4 \text { years }\end{array}$ & Tertiary care & $\begin{array}{l}\text { Cross- } \\
\text { sectional }\end{array}$ \\
\hline $\begin{array}{l}\text { Machado } \\
(2014)\end{array}$ & Brazil & 82 & $\begin{array}{l}\text { Hepatitis C-infected } \\
\text { patients in outpatient } \\
\text { clinic for viral } \\
\text { hepatitis, M } 52 \\
(63.4 \%) \text { F } 30 \text {; A } 45.1 \\
\text { years }\end{array}$ & $\begin{array}{l}\text { Secondary } \\
\text { care }\end{array}$ & $\begin{array}{l}\text { Cross- } \\
\text { sectional }\end{array}$ \\
\hline $\begin{array}{l}\text { Malbergier } \\
(2015)\end{array}$ & Brazil & 438 & $\begin{array}{l}\text { HIV-positive patients } \\
\text { on ART in a HIV } \\
\text { treatment center; M } \\
236(52 \%) \text { F } 213 \text {; A } \\
\text { 41.38 years }\end{array}$ & $\begin{array}{l}\text { Secondary } \\
\text { care }\end{array}$ & $\begin{array}{l}\text { Cross- } \\
\text { sectional }\end{array}$ \\
\hline $\begin{array}{l}\text { Martins } \\
(2012)\end{array}$ & Brazil & 123 & $\begin{array}{l}\text { Male patients with } \\
\text { liver disease in a liver } \\
\text { disease outpatient } \\
\text { unit; A } 42.64 \text { years }\end{array}$ & $\begin{array}{l}\text { Secondary } \\
\text { care }\end{array}$ & $\begin{array}{l}\text { Cross- } \\
\text { sectional }\end{array}$ \\
\hline
\end{tabular}




\begin{tabular}{|c|c|c|c|c|c|}
\hline $\begin{array}{l}\text { Meneses- } \\
\text { Gaya (2010a, } \\
\text { 2010b) }\end{array}$ & Brazil & 530 & 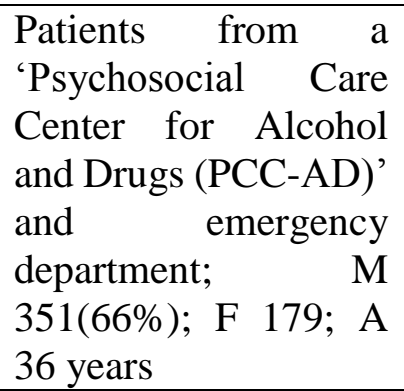 & Tertiary care & $\begin{array}{l}\text { Cross- } \\
\text { sectional }\end{array}$ \\
\hline $\begin{array}{l}\text { Morilha } \\
(2015)\end{array}$ & Brazil & 146 & $\begin{array}{l}\text { Patients with acute } \\
\text { coronary syndrome } \\
\text { (ACS) admitted to the } \\
\text { hospital; M } 95 \\
(65.1 \%) \text {; F } 51\end{array}$ & Tertiary care & Cohort \\
\hline $\begin{array}{l}\text { Pinheiro } \\
(2006)\end{array}$ & Brazil & $\begin{array}{l}386 \\
\text { couples }\end{array}$ & $\begin{array}{l}\text { Couples living in an } \\
\text { urban area; A } 30.3 \\
\text { years }\end{array}$ & Community & $\begin{array}{l}\text { Cross- } \\
\text { sectional }\end{array}$ \\
\hline $\begin{array}{l}\text { Zucoloto } \\
(2013)\end{array}$ & Brazil & 284 & 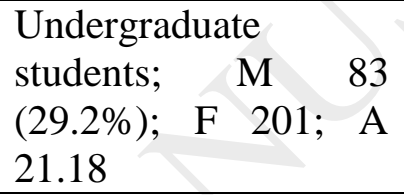 & Community & $\begin{array}{l}\text { Cross- } \\
\text { sectional }\end{array}$ \\
\hline $\begin{array}{l}\text { Herrera } \\
(2015)\end{array}$ & Peru & 399 & $\begin{array}{l}\text { MSM and transgender } \\
\text { women in sexually } \\
\text { transmitted infection } \\
\text { (STI) clinics; M } 310 \\
(77.7 \%) \text {; F 89; median } \\
\text { age } 30 \text { years }\end{array}$ & $\begin{array}{l}\text { Secondary } \\
\text { care }\end{array}$ & $\begin{array}{l}\text { Cross- } \\
\text { sectional }\end{array}$ \\
\hline $\begin{array}{l}\text { Ludford } \\
\text { (2013) }\end{array}$ & Peru & 5148 & $\begin{array}{l}\text { Sexually active men } \\
\text { who have sex with } \\
\text { men (MSM); A } 29.5 \\
\text { years }\end{array}$ & Community & $\begin{array}{l}\text { Cross- } \\
\text { sectional }\end{array}$ \\
\hline $\begin{array}{l}\text { Strunin } \\
\text { (2013) }\end{array}$ & Mexico & $\begin{array}{l}27,046 \\
\text { (high } \\
\text { school) } \\
22,417 \\
\text { (university) }\end{array}$ & $\begin{array}{l}\text { Public high school and } \\
\text { university students; M } \\
24,237 \quad(49 \%) ; \quad \mathrm{F} \\
25,226 ; \text { In high school } \\
67.5 \% \text { were age } 15 \\
\text { and in university } 56 \% \\
\text { were } 18 \text { years old }\end{array}$ & Community & $\begin{array}{l}\text { Cross- } \\
\text { sectional }\end{array}$ \\
\hline $\begin{array}{l}\text { Ansoleaga } \\
(2013)\end{array}$ & Chile & 12781 & 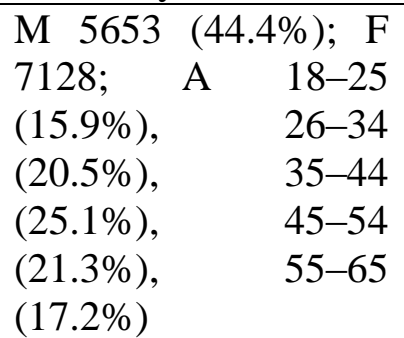 & Community & $\begin{array}{l}\text { Cross- } \\
\text { sectional }\end{array}$ \\
\hline
\end{tabular}




\begin{tabular}{|l|l|l|l|l|l|}
\hline Santis (2009) & Chile & 95 & $\begin{array}{l}\text { Adolescent students } \\
\text { attending pommunity } \\
\text { school; M 53 (55.8\%); } \\
\text { F 42; A 15.9 years }\end{array}$ & $\begin{array}{l}\text { Cross- } \\
\text { sectional }\end{array}$ \\
\hline
\end{tabular}


Table 2: Studies that did not examine the psychometric properties of AUDIT cut-off scores used

\begin{tabular}{|c|c|c|}
\hline Author (Year) & Country & Cut-off score(s) used or recommended \\
\hline Blair (2017) & Uganda & $>3$ (hazardous use) \\
\hline Kanyoni (2015) & Rwanda & $\begin{array}{l}\text { 8-15 (medium level of alcohol dependence) } \\
\geq 16 \text { (high level of alcohol dependence) }\end{array}$ \\
\hline Abayomi (2013) & Nigeria & $\geq 5$ (hazardous use) \\
\hline Brisibe (2011) & Nigeria & $\begin{array}{l}\geq 8 \text { (abuse/harmful use) } \\
\geq 20 \text { (alcohol dependence) }\end{array}$ \\
\hline Farley (2010) & Nigeria & $\geq 8$ or $\geq 10$ (hazardous use) \\
\hline Goar (2011) & Nigeria & $\begin{array}{l}\text { 4-7 (harmful use) } \\
\geq 8 \text { (hazardous use [alcohol abuse]) }\end{array}$ \\
\hline Issa (2012) & Nigeria & $\begin{array}{l}0-4 \text { (moderate alcohol use) } \\
\geq 5 \text { (hazardous use) }\end{array}$ \\
\hline Obadeji (2015) & Nigeria & $\begin{array}{l}0-4 \text { (moderate use }) \\
\geq 5 \text { (hazardous use })\end{array}$ \\
\hline Olisah (2009) & Nigeria & $\begin{array}{l}5 \text { to } 6 \text { (hazardous use) } \\
7 \text { to } 8 \text { (alcohol abuse) } \\
\geq 9 \text { (alcohol dependence) }\end{array}$ \\
\hline Ndetei (2009) & Kenya & $\begin{array}{l}\text { 4-12 (normal) } \\
13-18 \text { (harmful use) } \\
\geq 19 \text { (alcohol dependence) }\end{array}$ \\
\hline Nakhli (2011) & Tunisia & >13 (alcohol dependence) \\
\hline Adams (2013) & South Africa & $\begin{array}{l}\geq 8 \text { (harmful or hazardous use) } \\
\geq 13 \text { in women, } \geq 15 \text { in men (alcohol } \\
\text { dependence) }\end{array}$ \\
\hline May (2018) & South Africa & $\begin{array}{l}>4 \text { (current alcohol use at the light to moderate } \\
\text { range and above) } \\
\geq 8 \text { (problem or heavy drinking) }\end{array}$ \\
\hline Nothling (2013) & South Africa & $\begin{array}{l}\geq 8 \text { (alcohol abuse }) \\
\geq 13(\text { alcohol dependence })\end{array}$ \\
\hline Parry (2014) & South Africa & Men: \\
\hline
\end{tabular}




\begin{tabular}{|c|c|}
\hline & $\begin{array}{l}\text { Six or more drinks on one occasion at least } \\
\text { weekly, and score no more than } 22 \text { on the } \\
\text { AUDIT (harmful/hazardous use) } \\
\text { Women: } \\
\text { Four or more drinks on one occasion at least } \\
\text { weekly, and score no more than } 22 \text { on the } \\
\text { AUDIT (harmful/hazardous use) }\end{array}$ \\
\hline Simbayi (2004) & $\begin{array}{l}\geq 9 \text { (may be at risk or who are experiencing } \\
\text { alcohol problems) } \\
\geq 13 \text { (likely alcohol use problems) }\end{array}$ \\
\hline Simbayi (2006) & $\begin{array}{l}\geq 9 \text { (possible risk for alcohol problems) } \\
\geq 13 \text { (probable alcohol use problems) }\end{array}$ \\
\hline Vythilingum (2012) South Africa & $\begin{array}{l}>6 \text { (risky drinking) } \\
>20(\text { alcohol dependence })\end{array}$ \\
\hline Luitel (2017) Nepal & $>9$ (alcohol abuse or alcohol dependence) \\
\hline Luitel (2018) & $>9$ (alcohol abuse or alcohol dependence) \\
\hline Dasgupta (2013) & $\begin{array}{l}\geq 8 \text { (hazardous and harmful use) } \\
\geq 12 \text { (alcohol dependence) }\end{array}$ \\
\hline D'Costa (2007) & $\geq 8$ (harmful use or dependent drinking) \\
\hline Ghosh (2012) & $\begin{array}{l}\geq 8 \text { (hazardous or harmful use) } \\
\geq 13 \text { (alcohol dependence) }\end{array}$ \\
\hline Jonas (2014) & $\begin{array}{l}\geq 8 \text { (hazardous use) } \\
\text { Women: } \geq 13 \text { (alcohol dependence) } \\
\text { Men: } \geq 15 \text { (alcohol dependence) }\end{array}$ \\
\hline $\begin{array}{l}\text { Nadkarni }(2017 a, \quad \text { India } \\
\text { 2017b); Patel } \\
(2014)\end{array}$ & 12-19 (harmful use) \\
\hline Pal (2007) & $\begin{array}{l}8 \text { or } 9 \text { (hazardous use) } \\
\geq 10 \text { (alcohol dependence) }\end{array}$ \\
\hline Sau (2017) & $\begin{array}{l}\geq 8 \text { (alcohol use in excess of low risk) } \\
\geq 16 \text { (harmful and hazardous use) } \\
\geq 20 \text { (alcohol dependence) }\end{array}$ \\
\hline Chen (2013) & $\begin{array}{l}\geq 8 \text { (probable drinking problem }) \\
\geq 13 \text { (probable alcohol dependence })\end{array}$ \\
\hline
\end{tabular}




\begin{tabular}{|c|c|c|}
\hline & & $\begin{array}{l}\text { 0-7 (low risk drinking) } \\
\text { 8-15 (risk drinking) } \\
\text { 16-19 (heavy drinking) } \\
\text { 20-40 (hazardous drinking) }\end{array}$ \\
\hline Yee (2014) & Malaysia & $\geq 5$ (potential alcohol abuse) \\
\hline Sekulic (2012) & Bosnia and Herzegovina & $\begin{array}{l}\geq 11 \text { (harmful drinking) } \\
\leq 10 \text { (non-harmful drinking) }\end{array}$ \\
\hline Lasser (2018) & Russia & $\begin{array}{l}\text { Women: } \geq 13 \text { (alcohol dependence) } \\
\text { Men: } \geq 15 \text { (alcohol dependence) }\end{array}$ \\
\hline Domingues (2011) & Brazil & $\begin{array}{l}<8 \text { (not diagnosable alcohol problem) } \\
8 \text { to } 11 \text { (concerning consumption of alcohol) } \\
12-15 \text { (serious indication of a drinking } \\
\text { problem) } \\
>15 \text { (drinking problem) }\end{array}$ \\
\hline Luna (2014) & Brazil & $\begin{array}{l}\geq 8 \text { (harmful or hazardous drinking) } \\
\text { Women: } \geq 13 \text { (alcohol dependence) } \\
\text { Men: } \geq 15 \text { (alcohol dependence) }\end{array}$ \\
\hline Machado (2014) & Brazil & $\begin{array}{l}\geq 8 \text { (harmful use) } \\
8-15 \text { (mild cases) } \\
\geq 169 \text { (severe cases--high risk consumption) }\end{array}$ \\
\hline Malbergier (2015) & (n) & $\geq 8$ (harmful use) \\
\hline Martins (2012) & & $\begin{array}{l}\text { 8-15 (average-risk user) } \\
\geq 16 \text { (high-risk user or with likely diagnosis of } \\
\text { mental disorder related to the use of alcohol) }\end{array}$ \\
\hline Morilha (2015) & Brazil & $\begin{array}{l}\leq 7 \text { (hazardous use) } \\
\geq 8 \text { (harmful use) } \\
\geq 20 \text { (alcohol dependence) } \\
\leq 7 \text { (low-risk drinking) } \\
\geq 8 \text { (high-risk alcohol abuse) } \\
\geq 20 \text { (alcohol dependence) }\end{array}$ \\
\hline Pinheiro (2006) & Brazil & $\geq 10$ (alcohol related disorder/alcohol misuse) \\
\hline Herrera (2015) & Peru & $\geq 17$ (severe alcohol use disorder) \\
\hline Ludford (2013) & Peru & $\begin{array}{l}\geq 20 \text { (alcohol dependence) } \\
17-19 \text { (harmful use) } \\
8-16 \text { (hazardous use) }\end{array}$ \\
\hline
\end{tabular}




\begin{tabular}{|c|c|c|}
\hline Strunin (2013) & Mexico & $\begin{array}{l}\geq 3 \text { (hazardous or harmful use) for high school } \\
\text { students } \\
\geq 6 \text { (hazardous or harmful use) for university } \\
\text { students }\end{array}$ \\
\hline Ansoleaga (2013) & Chile & $\geq 6$ (hazardous use) \\
\hline
\end{tabular}


Table 3: AUDIT Validation Studies

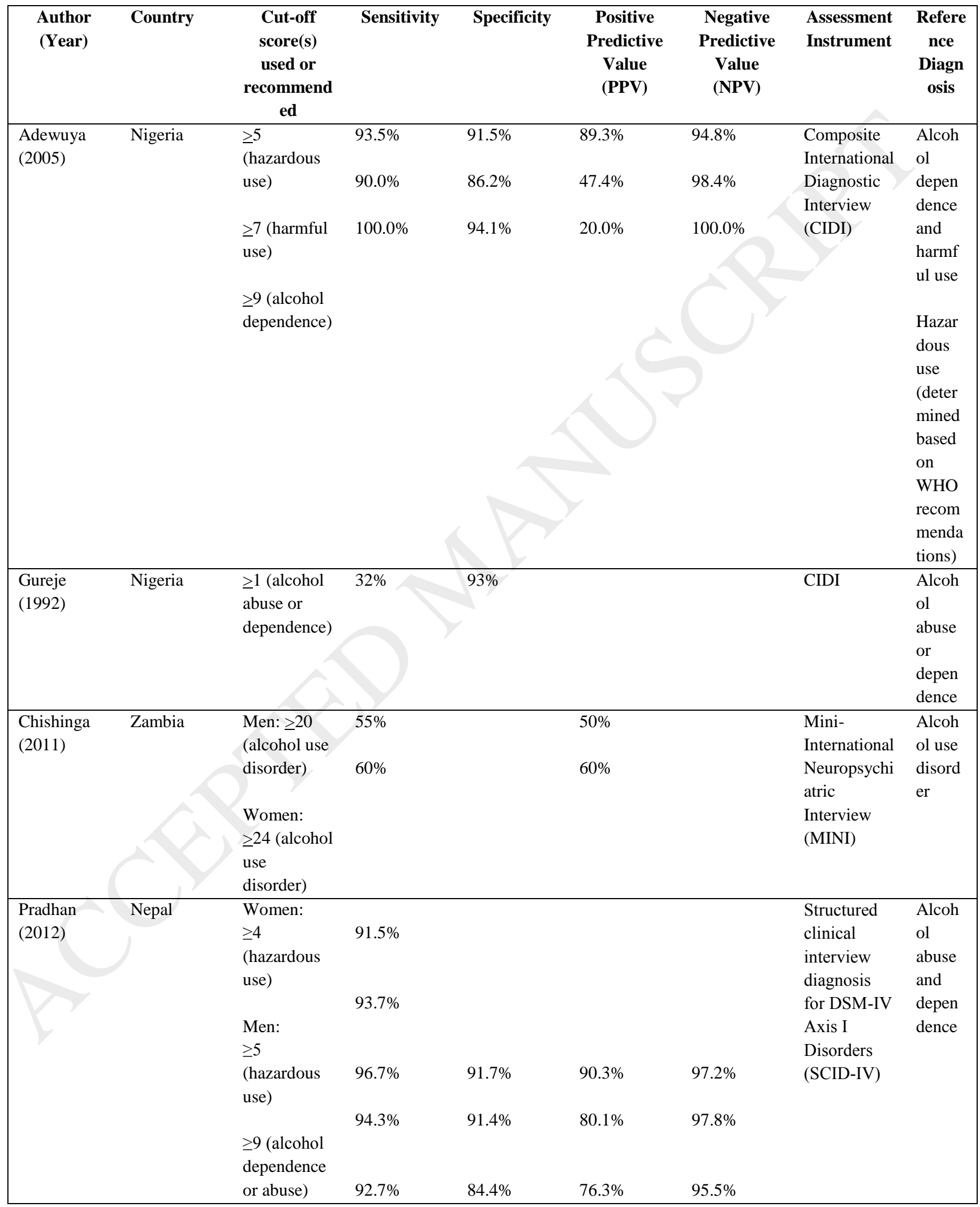




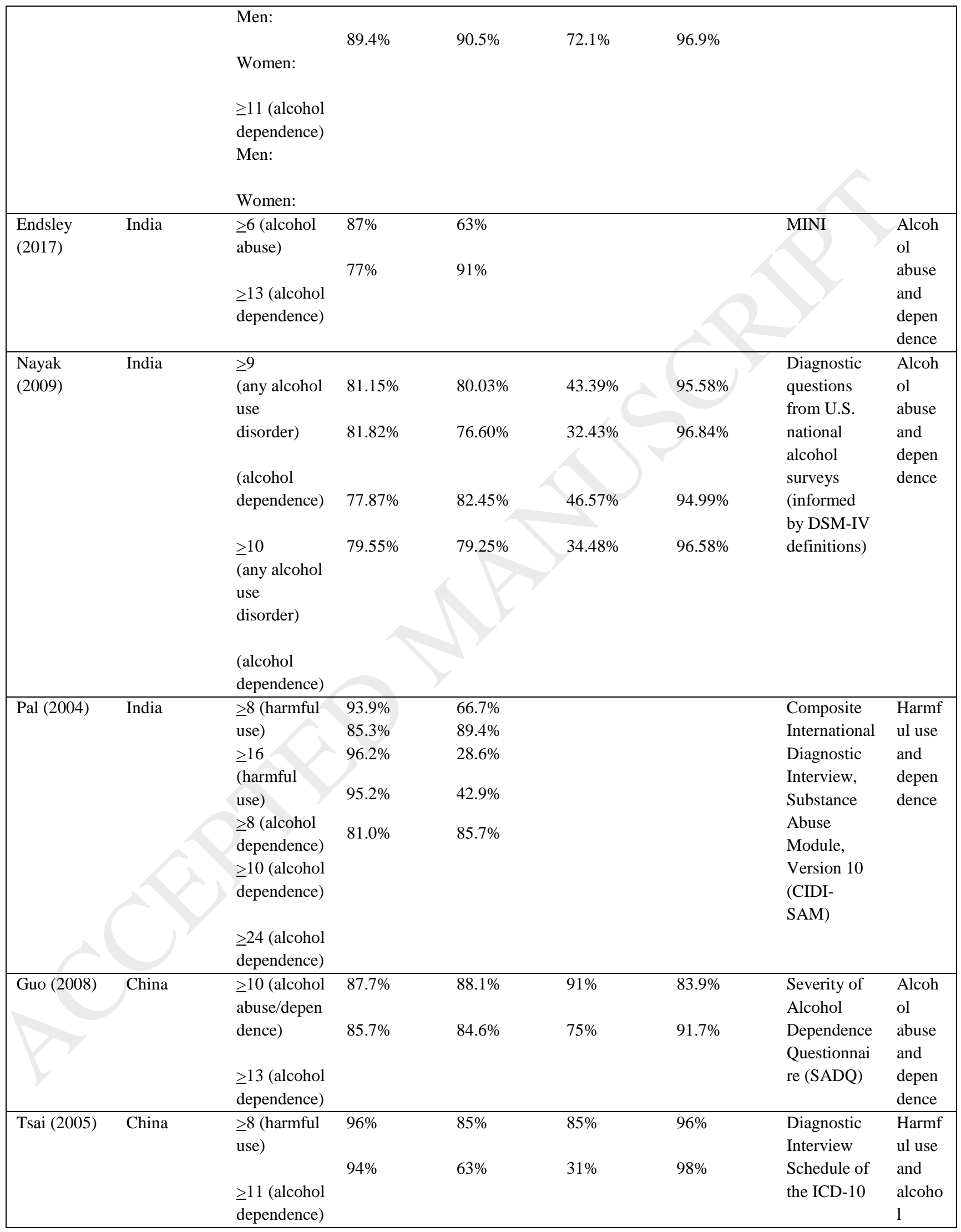




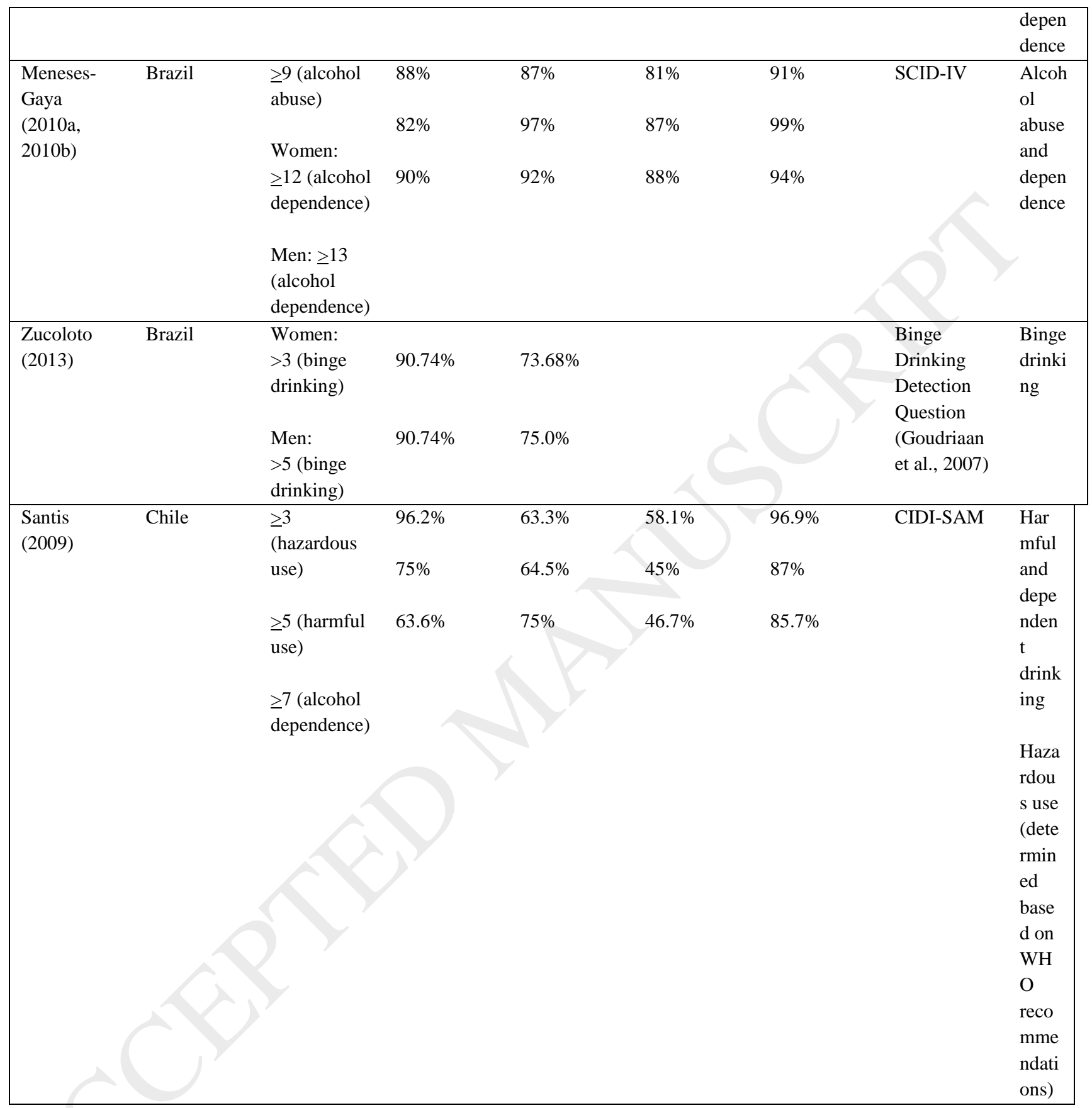

